\title{
A CENTRALIDADE ROMANA NOS ALVORES DA CONSTRUÇÃO DE UMA IMAGEM IMPERIAL POR PARTE DO REINO DE PORTUGAL
}

THE ROMAN CENTRALITY AT THE DAWN OF THE CONSTRUCTION OF AN IMPERIAL IMAGE BY THE KINGDOM OF PORTUGAL

Paulo Catarino Lopes * peclopes@gmail.com

RESUMO: Este artigo pretende abrir caminho para uma reflexão sobre o papel central desempenhado por Roma nos primórdios da edificação de uma imagem imperial por parte do reino de Portugal. A análise desenvolve-se com base num estudo de caso centrado no testemunho veiculado por um inédito documento português da aurora do século XVI. Dito de outra forma, trata-se de examinar este olhar original sobre o contributo de Roma - em anos de proto-globalização - no que respeita ao estabelecimento de uma nova linguagem simbólica e de representação do poder pela monarquia portuguesa face às restantes potências europeias. Segundo o anónimo autor, Roma é uma cidade global, que desempenha um papel decisivo na formação do império luso. Mas o que fundamenta este seu discurso? O que está na base de tal perspectiva? E que papel é, efectivamente, esse representado pela Cidade Eterna?

PALAVRAS-CHAVE: Roma; Império; Portugal.

ABSTRACT: This paper intends to open the way for a reflection on the central role played by Rome in the early days of the construction of an imperial image from the kingdom of Portugal. The analysis is developed based on a case study focused on the testimony served by an unpublished Portuguese document from the dawn of the sixteenth century. In other words, it is to examine this unique vision at the contribution of Rome - in years of proto-globalization - as regards the establishment of a new symbolic language and of power representation by the Portuguese monarchy face the other European powers. According to the anonymous author, Rome is a global city, which plays a decisive role in the formation of the Portuguese empire. But what underlies his discourse? What is the basis of such a perspective? And what role is in fact represented by the Eternal City?

KEYWORDS: Rome; Empire; Portugal.

Na aurora do século XVI, quando as nações ibéricas começam a estabelecer as bases para uma futura construção imperial, Roma, a capital da Cristandade, assume um papel central no jogo complexo de forças que então despoleta ao nível da política internacional europeia.

Um jogo de forças que envolve não apenas os reinos ibéricos, protagonistas (nesta fase inicial) inquestionados em relação ao mundo ultramarino, mas também as restantes nações ocidentais, em particular a todo-poderosa França, vencedora da Guerra dos Cem Anos, o Sacro Império e as principais potências italianas.

Este é o dinâmico e intenso período em que se opera a passagem da "pura" Republica Christiana à Europa das monarquias nacionais, cada vez mais centralizadas e cada vez mais

\footnotetext{
*Investigador Doutorado. Membro Integrado do Instituto de Estudos Medievais (IEM) e do Centro de História d'Aquém e d'Além-Mar (CHAM), ambos Unidades de Investigação da Faculdade de Ciências Sociais e Humanas da Universidade Nova de Lisboa (FCSH-UNL).
} 
fortes. Um período com profundas consequências políticas, sobretudo ao nível da relação entre as nações - basta referir, no que respeita à política externa, o nascimento da diplomacia moderna, expressa na sua forma acabada na figura do embaixador permanente (BELY, 2008).

Todo este processo configura-se e materializa-se no espaço da Península itálica, muito especificamente em Roma.

Disso dá conta, de forma particularmente reveladora, o anónimo Fidalgo português, criado do 4ㅇ duque de Bragança, D. Jaime, que parte de Chaves em direcção a Roma a 21 de Maio de 1510, para só regressar ao reino que o viu nascer em Setembro de 1517.

1. $O$ documento

Com base nesse périplo por terras italianas, o viajante flaviense redige, mais tarde ${ }^{1}$, um extenso relato intitulado Tratado que hum criado do duque de braguança escreveo pera sua senhoria dalgumas notauees cousas que vio hindo pera Roma. E de suas grandezas $E$ Jndulgençias, E grandes aconteçimentos que la soç̧ederam em espaço de sete años que hi esteue $^{2}$, em cujos fólios faz desfilar toda a complexidade das relações políticas internacionais que têm lugar na capital da Cristandade na aurora de Quinhentos.

A quase totalidade do conteúdo deste testemunho - que passou a ser conhecido como Memórias de um Fidalgo de Chaves $^{3}$ - reporta a acontecimentos e figuras que tiveram lugar em Itália, num arco temporal que podemos situar entre 1510 e 1517, período durante o qual o inominado autor aí viveu.

Representativo de uma época e de um espaço cruciais da história europeia, este documento constitui um testemunho privilegiado de um olhar "português" sobre a Roma do dealbar do século XVI enquanto espaço político-religioso fundador onde as grandes potências coevas disputavam a hegemonia sobre o Velho Continente (SALMANN, 2003). Noutra

\footnotetext{
${ }^{1}$ As pistas fornecidas pelo autor quando combinadas com os dados que hoje dispomos, permitem concluir que a redacção do texto final não tenha acontecido antes de meados de Julho de 1521 e em momento posterior ao início de Dezembro do mesmo ano.

2 Integrado na Colección de Don Luis de Salazar y Castro da Academia de História de Madrid com a classificação N-76 / Varios Portugueses (Signatura 9/I.081, hojas 136 a 227v), este documento ocupa os fólios 136r - 227v de uma miscelânea portuguesa, manuscrita e encadernada em pergaminho, que totaliza 250 fólios e contém 39 peças. Trata-se muito provavelmente da cópia manuscrita de um original perdido em língua portuguesa, de autor anónimo. Apesar de não incluir qualquer data, o longo manuscrito, constituído por 92 fólios redigidos ao que tudo indica por um único copista, apresenta uma caligrafia que o coloca cronologicamente na segunda metade do século XVI.

${ }^{3}$ A partir daqui, a designação da obra surge sempre de forma abreviada: Memórias.
} 
vertente, constitui um espelho fiel da forma original como o poder régio luso passa a "mostrarse" na capital da Cristandade. Uma forma que envolve toda uma nova e dinâmica semântica ao nível da linguagem de poder, da propaganda política e, enfim, da representação simbólica de uma autoridade que se quer, aos olhos da restante Cristandade, como verdadeiramente "imperial".

Nesta medida, as Memórias permitem perscrutar indícios que ajudam na obtenção de respostas para algumas questões fundamentais: numa época em que Portugal está predominantemente virado para o Atlântico e os Novos Mundos, existiam contactos políticos de absoluta prioridade com a capital da Cristandade? Se sim, qual a natureza e impacto desses contactos? Qual a posição de Portugal relativamente às grandes querelas europeias de então, que tinham por cenário a Itália e, mais especificamente, a capital da Cristandade? Roma ainda mantém uma centralidade fundadora, cujo peso pode ser decisivo na arbitragem de disputas internacionais entre as potências europeias à época em ascensão? Corresponde, de facto, o complexo início de Quinhentos a uma nova era na forma de fazer política externa? Em caso positivo, verifica-se uma relação com a emergência das monarquias nacionais e das grandes Casas dinásticas europeias, nomeadamente Portugal enquanto nação pioneira na construção de um império além-mar?

O (único) destinatário do texto é o emergente 4ㅇ duque de Bragança, D. Jaime (14791532) 4: "E feita oração me fui apousentar A çidade onde estiue sete anos E onze dias, trabalhando neste tempo de ver E de saber as cousas notauees que se em Roma E naquellas partes passaram pera dellas saber dar conta a vossa Jlustrissima senhoria." (Memórias, fl. 139v).

No que diz respeito à classificação do género narrativo, o texto oriundo da pena do Fidalgo de Chaves ao mesmo tempo que apresenta grande fluidez informativa e eclectismo de temas e situações, alimenta-se directamente do histórico e do factual. Isto faz com que o registo do texto se cruze com géneros tão diversos como o relato de viagens, a autobiografia,

\footnotetext{
${ }^{4}$ No dia 20 de Junho de 1483, em Évora, por ordem do rei D. João II de Portugal, foi executado o 30 duque de Bragança, D. Fernando II (1430-1483). Tal acto fundamentou-se na alegada prova de participação numa conjuração política contra a coroa portuguesa. Como consequência de todo este processo e por indústria de sua mãe, Isabel de Viseu (1459-1521), irmã do futuro rei D. Manuel I, os descendentes do malogrado duque viramse exilados na vizinha Castela, onde beneficiariam da proteç̧ão dos Reis Católicos. Serão treze anos de exílio até à restauração da Casa de Bragança, em 1496, pelo novo monarca, D. Manuel I. A partir desta data arranca, de forma contínua e irreversível, a recuperação e engrandecimento dos Estados brigantinos.
} 
as memórias, a missiva (no sentido de carta de conteúdo político), a epístola de carácter pessoal, o diário, a crónica urbana ou de cidade (na medida em que experimenta a narração de cenas de rua e de movimentações colectivas), a relação e, por último, o relatório. A haver um género será, portanto, misto e remetendo sempre para a categoria geral de história. 0 que, por sua vez, faz com que a intenção de verdade - expressa, por exemplo, no recurso à cópia de documentos oficiais - sirva de instrumento de certificação e legitimação da mensagem transmitida. Ou seja, o índice verdade é determinante no texto, na medida em que constitui o seu objecto último: dar a ver ao destinatário da narrativa, ainda que filtrado pelo juízo avaliador do autor, o que se passou durante os sete anos em que este permaneceu na capital da Cristandade (AMADO, 1997).

O Fidalgo assistiu em primeira mão aos acontecimentos que evoca e redigiu o seu texto em anos não muito distanciados dos eventos que narra. A sua escrita apresenta um estilo predominantemente livre e espontâneo, em boa parte fruto do facto de não estar sujeito à pressão oficial de uma missiva de carácter régio 5 .

\section{A Europa da aurora de Quinhentos: breve contextualização}

O período de viragem entre Quatrocentos e Quinhentos assistiu a um triplo processo de deslocação dos poderes. Em primeiro lugar, devido ao movimento de transcontinentalização da civilização europeia, cujos efeitos, circunstanciais no início, rapidamente passaram a influir no equilíbrio de poderes no seio do próprio continente europeu. Depois, verificou-se uma aceleração do processo de centralização do poder nas monarquias mais importantes da Cristandade - aqui sobressaem a França e a Espanha, que vão disputar a hegemonia sobre a Europa, num processo que marcará grande parte do século XVI e que terá como palco privilegiado a esplendorosa Itália (GREGOROVIUS, 1972) ${ }^{6}$. E, por último, o Turco impôs o seu poderio na "porta" oriental da Europa, de que a conquista de Constantinopla em 1453 foi uma decisiva etapa, numa dinâmica de crescimento imperial que condicionou fortemente a história do continente no século XVI (TURNBULL, 2003).

À data da partida do Fidalgo de Chaves para Roma, boa parte do território europeu estava longe de ter linhas de fronteira definidas. A Norte e a Leste, zonas periféricas, o

\footnotetext{
${ }^{5}$ Veja-se, como exemplo paradigmático, a descrição da embaixada portuguesa de obediência ao papa Leão $\mathrm{X}$, em 1514 (Memórias, fls. 178r a 179v).

${ }^{6}$ A materialização última desta disputa são as Guerras de Itália, que se desenrolam em solo italiano entre 1494 e 1559.
} 
processo de integração plena nas dinâmicas políticas, sociais e culturais do continente será longo. O Centro e a região itálica, por sua vez, constituíam uma realidade política completamente fragmentada. Já na parte ocidental dão-se passos firmes no sentido de uma definição política e fronteiriça (apesar de lenta e difícil, sobretudo em Espanha): seja em Portugal, Espanha, França ou Inglaterra, a realidade mostrava que doravante o processo, com avanços e recuos, da centralização régia era o futuro - quer sob o ponto de vista político, quer no que diz respeito aos dispositivos administrativo e simbólico do poder. Com efeito, em qualquer um dos casos, quer no plano interno quer ao nível externo, o princípio político orientador foi sempre a criação duma monarquia forte de carácter nacional.

Só cerca de um século mais tarde as divisões políticas da Europa iriam conhecer uma maior clarificação. Mas ao mesmo tempo, foi a partir deste período, o início do século XVI, que o Velho Continente, sempre em transformação e recomposição, começou a definir-se em termos de pensamento político: a procura do equilíbrio de poder entre potências - em particular as monarquias nacionais, à época em franca ascensão e afirmação - será o caminho a seguir, ao invés da unidade europeia tão almejada pelo sacro imperador, num impulso ideológico ainda, em parte, medievalizante (TENENTI, 1985). Esta será, efectivamente, a pedra-de-toque no futuro político da Europa.

Portugal, situado na periferia da Europa tornada centro com as Descobertas e os movimentos de expansão marítima, apresenta uma unidade política consolidada, apesar de todas as vicissitudes que marcaram a segunda dinastia real, bem como uma estável definição territorial desde o final da Reconquista (1249) e o Tratado de Alcanices (1297).

Os reinados de D. João II (1455-1495)7 e D. Manuel I (1469-1521, rei desde 1495) fazem Portugal operar uma viragem significativa em direcção a um novo rumo, onde o reforço da autoridade régia a nível interno ${ }^{8}$ e a abertura de Portugal ao mundo, ou seja, a

\footnotetext{
7 D. João II de Portugal sucedeu ao seu pai (Afonso V, 1432-1481, rei desde 1438) após este abdicar, em 1477, mas só ascendeu ao trono após a sua morte, em 1481.

${ }^{8}$ No entanto, não constituem sinónimo de monopólio por parte da Coroa sobre todos os aspectos de governação do reino. Ou seja, existe uma tentativa de centralização político-administrativa sim, mas sem que esta se torne um facto absoluto e plenamente concretizado. Ao invés, o poder real coexistia ainda com outros poderes, dotados de uma esfera de jurisdição própria e da qual não abdicavam - desde a Igreja até aos municípios, passando pelos poderes senhoriais que não desapareceram inclusivamente nas convulsões do agitado reinado de D. João II (HESPANHA, 1982).
} 
predominância da política ultramarina, ao nível externo constituem a pedra-de-toque da governação régia.

\section{Roma é Caput Mundi}

Quando, "a xxbj. dias andados daguosto da sobredita era de 1510" (Memórias, fl. 139v), o Fidalgo de Chaves entra em Roma de imediato se apercebe que está perante uma cidade única, quer em termos políticos, quer a nível espiritual. Uma cidade tão complexa, populosa, diversificada, internacional e cosmopolita, que nenhuma outra capital se lhe podia comparar, nem Lisboa ou Sevilha, à época verdadeiros centros urbanos de carácter internacional devido ao trato que pelos seus portos passava (ARAÚJO, 1990)

Roma é, sem dúvida, o centro da atenção do viajante flaviense. O que o impressiona e é alvo do seu interesse é o que se passa na multifacetada capital da Cristandade.

Percebemos, pela descrição que efectua dos acontecimentos, que é na Cidade Eterna que se decidem as grandes disputas europeias, ainda que tenham lugar nos mais distantes pontos de Itália, em particular a nível bélico ${ }^{9}$. Seguindo a mundividência política e geoestratégica do autor, o destino da Europa passa necessariamente por Roma. É isso que transmite de forma clara a D. Jaime de Bragança.

\subsection{Sede espiritual do mundo cristão}

É por via do religioso e da espiritualidade que o simbolismo arquétipo da mirabili urbe marca mais intensamente o autor: no seu solo sagrado assentam as maiores igrejas do mundo e no ponto onde morreu o fundador da Igreja faz o papa Júlio II (1443-1513, pontífice desde 1503) ${ }^{10}$ erguer "a JgreJa de sam Pero, que acabandosse seraa a moor edefiçio de JgreJa do mundo" (Memórias, fl. 169r).

Daí que, ao chegar à Cidade Eterna, opere de imediato uma referência explícita à componente religiosa, tornando desde logo intrínseco à descrição da urbe o tópico central da sua condição de cúspide espiritual e de topónimo central no imaginário colectivo da

\footnotetext{
${ }^{9}$ Vejam-se, a título de exemplo, os fólios relativos às batalhas de Ravena (Memórias, fl. 154v a fl. 158r) e do Marignan (Memórias, fl. 209r a fl. 211r).

${ }_{10}$ Nascido Giuliano della Rovere, este frade franciscano sobrinho do papa Sisto IV (1414-1484, pontífice desde 1471) foi nomeado cardeal em 1471, pouco depois de o seu tio ascender ao pontificado. Ficou conhecido como "o Papa guerreiro" ou "o Papa terrível".
} 
comunidade dos fiéis. Mais do que Jerusalém, pois esta estava na posse dos infiéis, ao passo que Roma era possível visitar apesar de todas as dificuldades que tal deslocação implicava.

Roma era tangível, palpável. Já Jerusalém ou até mesmo Constantinopla, que caíra havia pouco mais de meio século na mão do Turco tornando-se simbolicamente a sua capital, inscreviam-se no universo do apenas imaginado.

No plano simbólico, na medida em que é edificada sobre o alicerce da crença, ela é uma bona opera ${ }^{11}$. Por isso constitui um modelo para os peregrini na terra e a glorificação última da Igreja e por extensão de todo o crente.

Como o autor refere, trata-se de uma cidade mártir, pois foi violentada e saqueada pelo infiel: "E sendo saqueada [Roma], E despoJados seus templos de todos seus tesouros fizeram da santissima JgreJa de são pero estrebaria de caualos [...] em poder dos Infiees." (Memórias, fls. 174r e 174v) O facto de ter recuperado de tão martirizado passado garanteIhe um profundo simbolismo espacial, bem como um papel central na estruturação da memória colectiva cristã. Residem aqui, afinal, boa parte dos fundamentos da sua dimensão de espelho da vontade global (de ascensão) da Cristandade e, consequentemente, da sua glorificação espiritual (FROMMEL, 2003).

Os monumentos cristãos da mirabili urbe deixam no autor uma impressão marcante, como comprova a descrição que faz da Igreja de S. Pedro e do processo que envolve a construção do novo templo em detrimento do antigo ${ }^{12}$ - o que per se constitui um precioso testemunho directo da própria dinâmica arquitectónica e artística da Roma de Quinhentos (DESWARTE-ROSA, 1985, p. 489-508).

Roma é o coração de todos os cristãos do mundo e o modelo a seguir pelos novos espaços sob domínio das nações da Cristandade. Dito de outra forma, as cidades em construção nos territórios recentemente ocupados pelos cristãos, em particular os ibéricos, têm necessariamente de ter a cidade papal e as suas edificações religiosas como arquétipo e referência primeira.

\subsection{Uma cidade cosmopolita, ícone cultural do Renascimento}

\footnotetext{
${ }^{11}$ Sobressai aqui o peso de toda uma herança medieval do imaginário cristão.

12 Veja-se a extensa passagem relativa a este templo no quadro da descrição das estações quaresmais de Roma (Memórias, fls. 189v a 193r).
} 
A visão da Roma profana impressiona igualmente o autor. Os costumes da cidade surpreendem-no a cada momento. Daí afirmar que "por Jsso hee Roma cabeça das çidades do mundo, que o que em outras partes seria grandemente estranhado E avido por desonesto, se tem ali por gentileza louvor E honrra E nobreza da corte." (Memórias, fl. 183v).

O Fidalgo simplesmente rende-se à energia e ao movimento da Cidade
Eterna:
este dia comem os cardeaes $\mathrm{E}$ os senhores Romanos aquelle manJar de
çezilia que se chama macarone o qual hee feito de massa de queiJo. E
mandam huns aos outros grandes baçios daquella Jguaria como as comadres
fazem em portugual com suas filhoos douos. (Memórias, fl. 182v);
estas Ruas sam Repartidas antre os cardeaes // pera as mandarem
aparamentar de suas tapeçarias. E hee cousa fermosa de ver tanta
avondança de Ricos E diuersas estorias de panos. (Memórias, fls. 204ve 205r)

Para ele, Roma remete sempre para o conceito totalizador e totalizante de Caput Mundi, pois nela tudo é universal, grande e grandioso: "sam João de latrão que hee cabeça de todalas JgreJas do mundo" (Memórias, fl. 159v).

A mirabili urbe é o centro simbólico de onde tudo emana e o ponto físico para onde tudo conflui. As suas «torres E paços dos cardeaes E grandes senhores» (Memórias, fl. 173v) impressionam tanto pela riqueza como pela vivacidade. Palácios, jardins e fontes são, assim, sempre de louvar (Memórias, fl. 176v).

Ao retratarem como a Roma da Idade Média se transforma aos poucos na Roma renascentista, ou seja, uma monumental cidade que apesar de continuar a ser a cabeça do mundo religioso cristão assume já, em simultâneo, uma outra faceta mais temporal e profana, intimamente ligada à ascensão da arte, da cultura, das festividades de carácter popular e também das conspirações políticas que minavam as grandes capitais e cortes europeias, as Memórias são bem o espelho de uma urbe que se quer capital e paradigma de regiões que não se limitam já apenas ao Velho Continente. Esta cidade cuja transformação física acompanha a mutação dos tempos, visa estabelecer uma influência de carácter global.

Por outro lado, ao narrar diversas embaixadas que chegam a Roma, o Fidalgo estende também a sua visão da cidade à dimensão civilizacional e cultural, projectando a urbe em dois sentidos de carácter antropológico: por um lado, enquanto elemento de unidade e diálogo entre as culturas europeias de base religiosa cristã; e, noutra vertente, enquanto local onde é possível contactar com o Outro essencialmente diferente, porque longínquo e exótico 
- o Outro nunca visto. Ambos os sentidos transformam Roma num diferencial horizonte de cultura $^{13}$.

Neste quadro, aliás, as gentes lusas assumiram um raro protagonismo, na medida em que possibilitaram à Europa presente na capital da Cristandade experienciar o encontro civilizacional com o Outro oriundo dos distantes territórios recentemente descobertos, ou seja, o habitante das periferias do mundo, que tanto encantou e excitou a imaginação do homem medievo.

Roma domina no início do século XVI, mostrando ao mundo a sua vocação natural de capital renascentista e da Cristandade. É esta a ideia que o autor transmite no seu relato: uma cidade que é fruto da imbricação entre a cidade verdadeira e a cidade imaginada/sonhada por um lado, pelos visitantes e peregrinos e, por outro, pelos que a mostram, ou seja, os detentores de poder (os papas) e os artistas que a redesenham como Rafael Sanzio (14831520), Donato Bramante (1444-1514) e Miguel Ângelo (1475-1564).

\subsection{Grande centro de poder político}

A Roma que o Fidalgo descreve não é apenas a sede espiritual da Cristandade. É também um espaço urbano que se quer assumir como o grande eixo político da Europa, pelo menos no sentido de que todas as nações cristãs de alguma forma têm de por lá passar - e mostrar - para fazer valer as suas pretensões internacionais. Será esse, porventura, o sentido inscrito nas palavras de Alberto de Carpi $(1475-1531)^{14}$, embaixador em Roma do Sacro Imperador Romano-Germânico Maximiliano I de Habsburgo, ao evocar "todo o pouo vniversal de Roma" (Memórias, fl. 180r).

A embaixada portuguesa de 1514 é o melhor exemplo deste estado de coisas: ao mesmo tempo que revela a capacidade de representação da casa reinante lusa, anuncia a

\footnotetext{
${ }^{13}$ As Memórias fazem, de facto, prova de ambas as circunstâncias: registos de alteridade relativamente ao Outro europeu (fls. 138r e 138v, 141v e 142r, 146r a 148r, 151r e 151v, 158v e 159r, 163r a 164r, 169v,

$202 v$ a $203 v$, 217v e 218r, entre muitas outras passagens) e ao Outro proveniente das novas paragens do mundo recentemente descobertas (fl. $178 \mathrm{v}$ a fl. 180r).

${ }^{14}$ Humanista e diplomata, Alberto Pio III de Carpi foi um príncipe italiano íntimo dos papas Médici e amigo de Pietro Bembo (1470-1547, cardeal desde 1538) e Ludovico Ariosto (1474-1533). Nascido apenas dois anos antes da morte de seu pai, teve como guardiães os tios, sendo um deles o humanista Giovanni Pico della Mirandola (1463-1494). Aqueles supervisionaram a sua educação, nomeando como tutor o tipógrafo italiano Aldo Manúcio (c.1449-1515). Durante a quase totalidade da sua carreira, Alberto de Carpi serviu como diplomata. Em 1508, destacou-se como um dos negociadores da Liga de Cambrai e, em 1510, tornou-se o embaixador do imperador Maximiliano I junto do papado.
} 
capitalidade diplomática romana. A mirabilia vrbe assume, pois, um papel central, podemos mesmo afirmar arquétipo, na fundação deste pioneiro império ibérico ultramarino.

Apesar de terem falhado os projectos medievais de domínio universal por parte do papa e do imperador, a verdade é que o primeiro ainda tem um peso importante, sobretudo em termos de reconhecimento internacional e de resolução de conflitos e disputas entre nações. As disputas internacionais entre nações ibéricas constituem um exemplo paradigmático. Desde logo, com o Tratado de Tordesilhas (1494) celebrado entre os reinos de Portugal e de Castela para dividir as terras descobertas e por descobrir por ambas as Coroas fora da Europa. Depois, entre os mesmo protagonistas, com o Tratado de Sintra (1509), que tinha por objectivo precisar em definitivo os limites entre as áreas de influência dos dois reinos no Norte de África (estabelecidos quinze anos antes no Tratado de Tordesilhas). Finalmente, entre Portugal e Espanha em relação à questão das ilhas de Maluco (1524-1529), materializada no Tratado de Saragoça, em 1529.

Por isso, embora seja inquestionável o enfraquecimento da chama da Christianitas, continua a vingar alto o referencial romano para o universo político internacional europeu: as casas reinantes da Europa cristã vão mostrar-se e procurar confirmação para o seu poder em Roma ${ }^{15}$. Têm de o fazer, pois é neste palco fundador, perante o herdeiro da cátedra de $\mathrm{S}$. Pedro, que encontram a legitimação última (a de carácter internacional) do seu governo e autoridade: "tendo tristão da cunha os neguoçios acabados como compria a seruiço del Rei partiosse de Roma na fim de maio. E atee embarcar suas cousas foram prosperas." (Memórias, fl. 200v).

A par da imagem de capital da Cristandade, eis, pois, que as Memórias veiculam igualmente a visão da cidade dos Césares como um poderoso centro de poder que chega ao mundo renascentista a conceber-se e anunciar-se com uma dimensão de dominância, sendo, portanto, também por essa que via que desempenha no Ocidente coevo um papel preponderante no imaginário colectivo.

Depois, é preciso não esquecer que Roma é, desde logo, a capital dos Estados Pontifícios, assumindo-se nessa medida como representação do poder temporal - é a cidade como centro nevrálgico de uma politização (e logo de uma burocratização) do espaço, um

\footnotetext{
${ }^{15}$ E é aí também que vão observar os concorrentes, adversários e potenciais aliados.
} 
elemento fundamental da política secular: "em Roma fazia [o papa Júlio II] huns grandissimos paços pera se apousentarem nelles todolos ofiçiaes da curia Romana." (Memórias, fl. 169r)

\section{A embaixada de Portugal a Leão X}

A descrição de delegações à cúria pontifícia, em particular as embaixadas de obediência ao papa ${ }^{16}$, constitui um exemplo maior nas Memórias, por um lado, da importância da política externa (e, consequentemente, das negociações diplomáticas) no desenvolvimento das relações entre as nações da Europa da Primavera de Quinhentos, e, por outro, da centralidade da Santa Sé no jogo político da Europa coeva.

Esta premissa ganha ainda maior validade quando aplicada à descrição da embaixada de obediência enviada por D. Manuel ao papa Leão X (1475-1521, pontífice desde 1513) ${ }^{17}$ como é de prever, o autor dá especial atenção à missão de Portugal, chegando mesmo a incluir a carta que Alberto de Carpi escreveu ao seu senhor, relatando em detalhe a embaixada de Tristão da Cunha (c. 1460-1540) ${ }^{18}$. Na essência, com tal descrição, o Fidalgo revela a capitalidade romana na legitimação do estabelecimento de um império pelo reino de Portugal.

Ao pretender edificar e fazer reconhecer um império, D. Manuel necessita de forma vital do reconhecimento internacional (leia-se do reconhecimento pelas restantes potências europeias) proporcionado pela capital da Cristandade, quer em termos espirituais, quer, sobretudo, em termos políticos. Dito de outro modo, Roma é literalmente a chave para a legitimação internacional de tal projecto - cabendo, nomeadamente, à Cruzada ${ }^{19}$ operacionalizar esta "ponte" espiritual e política entre ambas as entidades: por parte de

\footnotetext{
${ }^{16}$ Onde a festa, a propaganda ideológica e a simbologia do poder são núcleos estruturantes.

${ }^{17}$ Segundo filho de Lourenço, o Magnífico (1449-1492), Giovanni di Lorenzo de Médici, futuro papa Leão X, foi nomeado cardeal com apenas 16 anos.

${ }^{18}$ Cavaleiro do conselho de D. Manuel I, explorador, comandante naval e embaixador. Cf. António Alberto Banha de Andrade, História de um fidalgo quinhentista português, Tristão da Cunha, Lisboa, Instituto de História Infante Dom Henrique, 1974.

${ }^{19}$ As Memórias evocam por diversas vezes o conceito de guerra justa, que surge sobretudo relacionado com a figura das guerras de Cruzada, uma das sobreviventes utopias medievais que se revestiu de maior longevidade (THOMAZ, 2000). Expressão de uma mentalidade coeva, nomeadamente portuguesa, o autor assume de forma inequívoca a posição de que a guerra entre povos cristãos não tem legitimidade temporal ou espiritual (Memórias, fls. 173v a 176r). Os únicos conflitos armados válidos para as nações da Europa ocidental devem ser, pois, os que se desenvolvem por via do ideal cristão da Guerra Santa contra os inimigos da Igreja católica, a saber o Turco no duplo palco europeu e oriental, e o muçulmano norte-africano. Esta é, de facto, a única guerra legítima, onde um príncipe cristão pode correr o risco de "grandes mortes E perdas de suas Jentes» (Memórias, fl. 201v). Aquela que é merecedora de valimento religioso e, consequentemente, do beneplácito dos líderes espirituais católicos.
} 
Portugal pelo investimento, desenvolvimento e aplicação prática; e por Roma pela validação oficial (através das respectivas bulas) e pelo reconhecimento legitimador (fornecido, nomeadamente, na forma de celebrações em Roma aquando das vitórias cristãs ${ }^{20}$ e na forma de oferendas ao monarca luso ${ }^{21}$ ).

A descrição feita pelo Fidalgo da embaixada de obediência ao papa, enviada por D. Manuel em 1513 e que desfilou nas ruas de Roma no dia 12 de Março do ano seguinte, vem complementar um diversificado corpus documental onde se destacam, por um lado, os registos epistolográficos coevos enviados de Roma por embaixadores e participantes na embaixada $^{22}$ (referimo-nos essencialmente à missiva do embaixador português João de Faria, enviada para o reino apenas 6 dias após o desfile da embaixada, e às correspondências de Nicolau de Faria, remetida no mesmo dia da do embaixador, e Tristão da Cunha, enviada para Lisboa, para o Secretário de Estado António Carneiro, um mês decorrido sobre o desfile) e, por outro, os textos de Damião de Góis (1502-1574) e D. Jerónimo Osório (1506-1580), sendo que o primeiro se baseia grandemente nas referidas missivas (GOUVEIA, 1992).

Ora, as ditas correspondências lusas, ainda que coevas, constituem na essência textos oficiais enviados por participantes na própria embaixada, pelo que, de alguma forma, a imagem nelas fornecida é sempre condicionada pela expectativa a priori da entidade oficial que as recebe e as lê, ou seja, na grande maioria dos casos o rei e os seus principais representantes administrativos, como é o caso do secretário de Estado (JAUSS, 1985).

Já o texto de Damião de Góis, que data de 1566 (GÓIS, 1926, Vol. III, pp. 185-193), assim como a narrativa de D. Jerónimo Osório, datada de 1571 (OSÓRIO, 1944, pp. 127-131), ou até a do humanista e prelado italiano Paolo Giovio (1483-1552), que escreveu igualmente

\footnotetext{
${ }^{20}$ No caso específico das Memórias o momento paradigmático deste fenómeno são as festas e rituais religiosos celebrados em Roma pela tomada de Azamor, sob o comando de D. Jaime , 4ㅇ duque de Bragança (Memórias, fls. 173v a 176r), em 1513. O Fidalgo destaca neste quadro a emotiva pregação efectuada por «hum coneguo de são pero» (Memórias, fl. 173v) durante a missa solene proferida pelo próprio papa no «moesteiro de sancto agustinho" (Memórias, fl. 173v). O autor tem o cuidado de referir que, a dado momento do seu exaltado discurso, o cónego dirige-se especificamente aos embaixadores dos príncipes cristãos presentes na dita missa papal, evocando os feitos de D. Jaime e D. Manuel que se apresentam, desta forma, como os dignos herdeiros dos feitos da primeira Cruzada, uma época apresentada como de ouro na medida em que "os christãos guanharam aos Infiees sendo vnidos $E$ Juntos em hum acordo $E$ vontade, sahindo de suas terras com braço armado $E$ fee grande.» (Memórias, fl. 174r).

${ }^{21}$ Como a Rosa de Ouro e os prestigiados Gladius et Pileus, espada papal e barrete ducal (ANDRADE, 1974).

${ }^{22}$ Cf. "Carta do Doutor João de Faria a el-Rei, 1514 - Março 18" (Corpo Diplomatico Portuguez, 1983, pp. 234238); "Carta de Nicolao de Faria e el-Rei. 1514 - Março 18” (ibidem, p. 238-242); "Carta de Tristão da Cunha ao secretario de estado. 1514 - Abril 11." (ibidem, p. 242-243).
} 
sobre a embaixada, sendo o seu texto de 1551, são produções - ao contrário da do Fidalgo de Chaves - não coevas dos acontecimentos que relatam nem tão pouco fruto de um testemunho em primeira mão por parte dos autores (GIOVIO, 1568, p. 127).

O facto de o Fidalgo ter assistido em primeira mão aos acontecimentos e redigir o seu texto em anos não muito distanciados dos eventos que narra, associado à constatação de não estar sujeito à pressão oficial de uma missiva de carácter régio (ainda que o seu texto se dirija especificamente ao 4 으 duque de Bragança, provavelmente por solicitação deste), constitui um poderoso argumento na determinação do elevado valor histórico-cultural das suas Memórias, sobretudo em relação aos relatos supramencionados.

Mesmo que redigidas alguns anos após os acontecimentos, não se trata de um hiato de décadas como acontece com os autores indicados.

Logo no início do capítulo, o autor refere que a nau utilizada por Tristão da Cunha para transportar a embaixada era aquela que o seu senhor, D. Jaime, utilizara para conquistar Azamor (Memórias, fl. 178r). Com efeito, através desta pequena introdução à larga descrição que se segue, o Fidalgo opera uma ligação fundamental que não surge nas restantes descrições, mais ou menos coevas, da mesma embaixada: a do seu senhor, o único destinatário do relato, a um dos momentos mais altos da representação do reino de Portugal na capital da Cristandade.

A nau assume aqui um singular protagonismo pelo seu carácter áugure da notoriedade militar e expansionista (em particular no que diz respeito à fé cristã) de Portugal, pois, foi através dela que os portugueses passaram a África à conquista de uma das principais praças do Islão marroquino.

Após uma breve referência à chegada da delegação a Itália e às condições em que a mesma ocorre (Memórias, fl. 178r), o autor destaca a enorme expectativa por parte dos senhores romanos:

E nos dias que se deteueram sem fazer mostra da embaixada, as Jrmãas do papa $E$ muitos grandes senhores e senhoras foram ver o pontifical que el Rei mandaua A see apostolica, ho qual guarçia de Resende secretario da embaixada que ho tinha em poder amostraua a todos. E elles ficauam maravilhados da grande Riqueza das peças polla multidão do alJofre de que erão cubertas, E de muitos Robis e pedras preçiosas que nelle hião. E pollo conseguinte foram ver o alifante que ficara fora da çidade, por ser cousa nam 
vista em Roma segundo se dizia do tempo de Jullio çesar, nem em toda Jtalia, senam hum que avia poucos anos que viera a lombardia. (Memórias, fl. 178r)

De tal forma que a embaixada faz a sua entrada solene no primeiro domingo da Quaresma, época litúrgica muito especial no quadro das efemérides cristãs e, em particular, romanas.

Ainda antes de começar a descrição da comitiva realça a diversidade e o primor selectivo da assistência: "E Jaa todolos prelados E patriarchas, arçebispos E bispos, E os embaixadores do emperador $\mathrm{E}$ dos Reis $\mathrm{E}$ a familia do papa $\mathrm{E}$ todas as dos cardeaes erão hidos ao Reçeber." (Memórias, fls. 178r e 178v)

Em seguida, com um tom muito pessoal claramente fruto da pena de quem presenciou o acontecimento por si mesmo, o autor narra a entrada da embaixada. A ordem e a organização (atribuídas pelo mestre de cerimónias) constituem a pedra-de-toque do discurso (Memórias, fl. 178v.).

Com especial enfoque na estrutura social da embaixada, que se reflecte na ordem protocolar das precedências, o Fidalgo descreve o esplendor e o colorido do cortejo que atravessa a urbe em direcção ao castelo de Santo Ângelo, em cuja janela o papa assiste ao desfile (Memórias, fl. 178r e fl. 178v).

Após referenciar o brilhantismo trazido pelos músicos (Memórias, fl. 178v), o autor avança com a apresentação do índio e da onça, dois dos mais notáveis exemplos do exotismo da embaixada: "E o Jndio com a onça nas ancas do caualo vestido de seda." (Memórias, fl. 178v).

Concentra-se depois nos fidalgos, que surgem ricamente trajados (Memórias, fl. 178v). É o momento em que começa a individualizar numa clara tentativa de elevar a representatividade social e política dos embaixadores portugueses e, consequentemente, da embaixada no seu todo.

Evoca, entretanto, o elefante Hanno - a principal fonte de exotismo do cortejo -, em cujo dorso num cofre de luxo e riqueza sem igual está contido o pontifical, a outra grande oferenda ao novo pontífice:

vinha mais o alifante com albardilha de borcado sobre o qual hia hum cofre grande de çetim cremesim com lauores de crauação dourada no qual vinha metido o pontifical E ornamentos. E o dito cofre vinha cuberto de hum Reposteiro de borcado bandado de quartapisas de veludo cremesim que 
aRastraua pollo chão. E o alifante trazia as armas del Rei Ricamente brosladas na testa. ao pescoço huma grande campainha de prata. E o Indio que ho guovernaua vestido de seda com hum bastão na mão guarneçido de prata. (Memórias, fls. 178v e 179r)

Destaque especial também para o mahout ${ }^{23}$ indiano, outro elemento exótico que reflecte o poderio português além-mar. Afinal, é ele quem conduz o surpreendente animal, que a todos pasma de espanto.

Retomando o elemento nobre da delegação, eis que surgem os embaixadores, discriminados individualmente de acordo com o seu estatuto: "atraz dos sobreditos vinhão os embaixadores, scilicet, tristão da cunha em meo de João de faria estante Em Roma E dioguo pacheco orador." (Memórias, fl. 179r).

O que impressiona sobremaneira o Fidalgo é o esplendor dos embaixadores: Tristão da Cunha, embaixador da delegação, João de Faria, embaixador em Roma ${ }^{24}$, e Diogo Pacheco, orador da embaixada e responsável pela comunicação oficial: "E os ditos doutores João de faria E dioguo pacheco Ricamente vestidos E encavalguados." (Memórias, fl. 179r).

Em seguida, num modo de apresentação generalista e anónimo que garante, por isso, um maior destaque à componente lusa, surgem "os embaixadores do emperador $E$ dos Reis $E$ das senhorias que erão estantes em Roma, E grande multidão de prelados $E$ dinidades $E$ de outros senhores eclesiasticos E seglares [...] pareçia tam Rica E fermosa companhia ca toda Roma coRia a velos." (Memórias, fl. 179r).

Finalmente, a referência ao povo, base da pirâmide social, sempre enquanto espectador, mas cuja presença é indispensável para garantir o sucesso da embaixada: "E era Jente sem conto, mudandosse de humas Ruas As outras per trauessas E luguares donde os milhor podiam ver atee cheguar a suas pousadas." (Memórias, fl. 179r).

O cortejo da embaixada do rei de Portugal que desfilou por Roma, em 1514, teve eco pela Europa e, sobretudo, por toda a Itália. Seja na figura da correspondência de embaixadores $^{25}$, seja através das produções culturais de humanistas que ficaram

\footnotetext{
23 Tratador.

24 João de Faria foi o primeiro embaixador residente português na cúria papal. Nomeado por D. Manuel, ocupou o cargo entre Fevereiro de 1512 e Novembro de 1514, data em que foi sucedido por D. Miguel da Silva.

${ }^{25}$ Nomeadamente Lippomano, embaixador veneziano, e, como já referimos, Alberto de Carpi, embaixador do imperador Maximiliano.
} 
profundamente marcados pelo sucedido - em particular poemas e xilogravuras -, toda uma vasta e heterogénea herança foi deixada à Cristandade, constituindo a prova inequívoca do carácter excepcional da delegação ${ }^{26}$.

Através desta sumptuosa embaixada ao papa Leão $X$, o rei português afirmava-se como um dos mais poderosos soberanos do mundo. Foi este propósito propagandístico o principal objectivo da delegação e foi exactamente isto que o Fidalgo de Chaves tão bem transmitiu no seu relato: a construção viva de uma imagem e de uma simbólica de poder, perante os olhos e os ouvidos espantados (no sentido da mirabilia medieval) dos representantes de toda a Europa naquela que era a capital espiritual, política e cultural da Cristandade na viragem de Quatrocentos para Quinhentos:

o dia que avia de ser sua entrada [do elefante] se foi o papa com muitos cardeaes ao Jardim do castelo de santangelo $\mathrm{E}$ se pos a huma Janella donde se vee toda a Rua alexandrina ataa o sacro palaçio. [...] E Jaa todolos prelados E patriarchas, arçebispos E bispos, E os embaixadores do emperador $E$ dos Reis E a familia do papa $E$ todas as dos cardeaes erão hidos ao Reçeber.» (Memórias, fl. 178r e fl. 178v)

A embaixada portuguesa possui uma função política e social bem definida, tem uma morfologia, uma hierarquização dos seus elementos. No todo e nas partes, ela comunica através de várias linguagens: o gesto, o vestuário, o som, os comportamentos (humanos e animais; veja-se quando o elefante molha os circundantes para regozijo da assistência). E o grau de leitura está de acordo com os vários públicos que a ela assistem nas ruas de Roma:

cheguando A ponte de sancto angelo [,] onde o papa estaua, mandou Sua Santidade que se deteuesse pera ver ho que o alifante fazia. o Jndio lhe fez fazer muitas mesuras $\mathrm{E}$ dar bramidos $\mathrm{E}$ tomar aguoa na tromba $\mathrm{E}$ deitala aos que o papa mandaua. E deitaramlhe ducados no chão tomauaos com a tromba $\mathrm{E}$ dauaos ao Indio $\mathrm{E}$ assi outras moedas dahi pera baixo. E de o

\footnotetext{
26 Marcantonio Casanova, Joachim Cipellus, Aurelio Sereno, Alberto de Carpi (embaixador do imperador Maximiliano), Paulo Giovio (biógrafo do papa), Lippomano (embaixador de Veneza), Fabronio, (igualmente biógrafo papal), Paride de Grassi (mestre-de-cerimónias na corte de Leão X), Jacopo Sadoleto, Malespini Pasquale e Sebastião Tedallini foram alguns dos prestigiados escritores coevos, que, da política à poesia, comemoraram a missão de obediência portuguesa (ou seja, a gesta lusa além-mar e o poder de D. Manuel), bem como a chegada a Roma do elefante Hanno.

O próprio Leão X redigiria um epitáfio para colocar no memorial ao elefante Hanno concebido, a seu pedido, por Rafael Sanzio (1483-1520), ícone do Renascimento italiano e artista de eleição do pontífice. O memorial foi colocado na parede à entrada do Vaticano encontrando-se hoje perdido.

Hanno foi, de facto, inspiração na pintura e na escultura dos grandes artistas de Quinhentos. Rafael Sanzio pintou-o e utilizou-o largamente como tema. Também Giovanni Barili, mestre das madeiras para a basílica de São Pedro, elaborou uma reprodução sua, a única actualmente conhecida, num dos entalhamentos de uma das portas do Vaticano. As representações materializaram-se nos mais diversos meios: fresco, óleo, aguarela, gesso, lápis, tinta, mármore, entalhe (BEDINI, 1997, p. 59-63 e 238-240).
} 
alifante entender E fazer todo o que lhe o Indio mandaua erão o papa E os cardeaes marauilhados. (Memórias, fl. 179r)

É reveladora a preocupação do Fidalgo em fazer um relato quase visual da embaixada que desfilou por Roma a 12 de Março de 1514, chegando ao ponto de, como já referimos, transcrever a versão portuguesa da "Carta que o senhor de carpe embaixador do emperador maximiliano em Roma escreueo sobre a dita embaixada ao dito emperador." (Memórias, fl. 179v).

Aníbal Pinto de Castro destaca que, no seu todo, apesar de apresentar "uma formulação mais arcaizante e literal", a "versão do Fidalgo não diverge substancialmente daquela que Damião de Góis inclui no capítulo LVII da 3ạ Parte da Crónica do Felicíssimo Rei D. Manuel (depois copiada por D. António Caetano de Sousa nas Provas da História Genealógica), nem da de D. Jerónimo Osório no De Rebus Emmanuelis Gestis." (CASTRO, 1991, p. 10)

Tal como Damião de Góis (GÓIS, 1926, Vol. III, p. 193), para legitimar a sua representação da embaixada, a argumentação do Fidalgo baseia-se no recurso ao documento como prova e, consequentemente, como meio superior de demonstração. Reside aqui a justificação para a inclusão no relato da missiva do embaixador do imperador Maximiliano I. Desta forma, o destinatário do texto não terá qualquer dúvida acerca da veracidade dos factos (REBELO, 1991). Até porque, como seria de esperar de uma missiva dirigida ao Sacro Imperador Romano-Germânico, a carta de Alberto de Carpi é plena de minúcia e detalhe (Memórias, fls. 179v a 181r).

Como salienta Eugenio Asensio, o Fidalgo "pinta con lujo de pormenores el desfile de la embajada de Tristão da Cunha con Garcia de Resende y el elefante." (EUGENIO ASENSIO, 1970, p. 17) Já Aníbal Pinto de Castro, por sua vez, havia notado que a versão do Fidalgo acerca da embaixada de Tristão da Cunha apresenta uma "minúcia [que] ultrapassa por vezes a do próprio Garcia de Resende, mesmo sem ter em conta a transcrição da carta do Embaixador De Carpe" (CASTRO, 1991, p. 13).

Graças à sua diversidade animal, material e até humana, a embaixada de 1514 provocou no coração do Velho Continente o espanto pelas realidades extra-europeias, contribuindo de forma decisiva para a divulgação da gesta dos portugueses nos oceanos do mundo e para o despertar do interesse das restantes nações da Europa pelas navegações lusas 
(Memórias, fls. $179 v$ e $180 \mathrm{r}$ ). Atente-se na seguinte passagem da missiva do embaixador imperial, que destaca a heterogeneidade do público que assistia ao desfile: "todo o pouo vniversal de Roma coRia por ver esta nouidade, o que nam hee maravilha por que pouco ameude se faz que os prinçepes emviem leguados a Roma em assi grande Resplendor $E$ manifico aparelho." (Memórias, fl. 180r) Será este público a passar a mensagem acerca da magnificência e da novidade da embaixada para os mais diversos destinos europeus.

A embaixada tem sobretudo um carácter exótico, ou seja, transcontinental e é nisso, essencialmente, que difere e se distancia (em superioridade) de todas as outras que em Roma desfilaram perante o novo pontífice. Trata-se do desfile dos grandes viajantes e dos propagadores da fé cristã, trazendo consigo as maravilhas encontradas nas regiões recémdescobertas para a Cristandade. Esta é a marca matricial da embaixada de Tristão da Cunha, pelo que todos os elementos que a compõem têm sempre inerente a conotação do longínquo, e por isso sedutor, mundo além-mar.

E o exotismo não se limita ao elemento animal materializado no elefante e na onça. Estende-se igualmente ao precioso elemento humano, seja na figura do mahou ${ }^{27}$ indiano que conduz o elefante, seja pelo "Indio negro sobre hum fermoso caualo ornado de huma sella da India, o qual trazia atras si sobre as ancas do cauallo hua besta semelhauel ao lião pardo, mas de corpo mais graçioso E de muitas E desvairadas cores" (Memórias, fls. 179v e 180r), seja ainda através dos escudeiros negros que integram a embaixada: "muitos daquelles escudeiros erão negros E crespos E outros trosquiados E nam assi aluos como são os Jtalianos." (Memórias, fls. 179r e 179v)

É, afinal, desta componente de "raridade" que sobreleva a função propagandística e de símbolo e instrumento de poder da embaixada: a construção da imagem de D. Manuel enquanto príncipe cristão todo-poderoso, rodeado do exotismo do mundo, a quem os mais distantes monarcas prestam vassalagem - "era el Rei nosso senhor sobre todolos outros tido em maior veneração de catolico E christianissimo" (Memórias, fl. 179v). O mesmo se pode depreender das palavras do embaixador Alberto de Carpi: "a materia era preçiosa mas a obra sobrepoJaua aa materia, a qual era polla singular Religião E deuação deste prinçepe dada. [...]

\footnotetext{
27 Tratador.
} 
E nam hee de poer em silençio que haa estendido E engrandeçido nossa Religião com grande gloria atee os guaramantes E Jndios." (Memórias, fl. 180v)

Através da progressiva elevação da imagem de liberalidade, prosperidade e poder de D. Manuel, a embaixada de Tristão da Cunha reflecte, enfim, as ambições políticas - podemos mesmo afirmar imperiais (THOMAZ, 1990) - do projecto régio português:

era el Rei nosso senhor sobre todolos outros tido em maior veneração de catolico $\mathrm{E}$ christianissimo $\mathrm{E}$ bem aventurado em todas suas cousas como se amostraua pollas continuas festas que se em Roma faziam das victorias que Ihe nosso senhor daua contra os Infiees, assi em africa como na India [,] enRiqueçendo os seus $\mathrm{E}$ acreçentando seu estado $\mathrm{E}$ poderio. (Memórias, fl. 179v)

Por outro lado, visando as demais potências europeias, em particular as emergentes (a França e a Espanha), a embaixada de 1514 possui uma grande importância institucional na medida em que dá a ver uma nova imagem da relação entre o poder político português e o poder religioso e temporal da Santa Sé. Daí que, com uma profunda conotação política, se destine a um público que não é só o das ruas de Roma mas também o dos embaixadores, agentes, mercadores e nobres estrangeiros.

Mas, para além destes objectivos de carácter geral, que outros, mais concretos, teria a embaixada de 1514? Desde logo, a prossecução das sessões suspensas do Concílio de Latrão V (1512-1517), onde era debatida a questão estrutural da Reforma da Igreja. Depois, que fosse estabelecida uma liga defensiva e ofensiva dos reis cristãos para fazer face ao imparável avanço Turco que ameaçava a Europa ocidental e muito em particular, depois de Otranto, o coração da Cristandade. Em seguida que o pontífice autorizasse a realização de uma colecta temporária em determinados rendimentos do clero secular e religioso, com o propósito de financiar as actividades na Ásia e em África. Finalmente, a concessão "das muitas e mui importantes graças especiaes em cujo complexo está envolvido e amplificado o padroado das igrejas do Ultramar, que elle [D. Manuel] então pediu que fosse incorporado á ordem de Christo." (RESENDE, 1854, p. 219)

No geral, estes objectivos foram concretizados (à data da entrada de Tristão da Cunha na Cidade Eterna, os dois primeiros perderam validade), revelando-se a embaixada um sucesso, como se pode verificar através das respostas favoráveis de Leão X materializadas num conjunto de bulas e breves datados de entre 29 de Abril de 1514 e 30 de Janeiro do ano seguinte (Corpo Diplomatico Portuguez, 1983, p. 244-310). 
O próprio Fidalgo assinala este êxito no seu testemunho: "tendo tristão da cunha os neguoçios acabados como compria a seruiço del Rei partiosse de Roma na fim de maio. E atee embarcar suas cousas foram prosperas." (Memórias, fl. 200v); "Conçedidas as sobreditas graças a el Rei, pedio sua alteza ao papa nunçio pera hir a portugual dar as bulas de sua santidade a execução." (Memórias, fl. 200v).

Mas observemos um pouco mais em detalhe. A 29 de Abril de 1514 o papa começa por retribuir as oferendas de D. Manuel, assinando uma bula na qual contribui para o combate português contra os infiéis em África e na Ásia através do lançamento das terças nos frutos e rendas dos Mosteiros e Igrejas de Portugal ${ }^{28}$.

Em 11 de Maio do mesmo ano, o papa oferece a Rosa de Ouro ao monarca ${ }^{29}$ (D. Manuel já havia recebido uma de Júlio II, em 1506), que neste ano era também ambicionada pelo sacro imperador Maximiliano: "sua estada [de Tristão da Cunha] foi em Roma tres meses, por que foi neçessario mandar a el Rei avisos dos neguoçios a que viera, E esperar de sua alteza Reposta. no qual tempo Ihe foi dada a Rosa pera el Rei." (Memórias, fl. 200r) Ainda que de valor material exíguo, a peça revestia-se de enorme significado simbólico, pois além de se tratar de um costume ancestral, premiava um Príncipe cristão que tivesse manifestado particular devoção, sobretudo no que dizia respeito à expansão da fé, à causa da Igreja Romana.

Em bula de 7 de Junho ${ }^{30}$, Leão X confirma o direito de Padroado espiritual de toda a Igreja e mais benefícios de todas as terras do Ultramar, concedido pelos predecessores aos reis de Portugal, por incorporação na Ordem de Cristo.

Logo a seguir surge a bula Pro excellenti, datada de 12 do mesmo mês, criando o bispado do Funchal, com dignidade e cónegos $^{31}$. Esta graça atribuída pelo novo pontífice, como António Banha de Andrade salienta, "parecendo à primeira vista um assunto estritamente eclesiástico, não deixa de provocar profundas repercussões no revigoramento do Estado Português" (ANDRADE, 1974, p. 129), dado o avançado estado de desenvolvimento da Madeira, com particular incidência para a cidade do Funchal.

\footnotetext{
${ }^{28}$ Cf. "Bulla do Papa Leão X dirigida a el-Rei. 1514 - Abril 29" (Corpo Diplomatico Portuguez, 1983, pp. 244-248).

${ }^{29}$ Cf. "Breve do Papa Leão X dirigido a el-Rei. 1514 - Maio 11" (Corpo Diplomatico Portuguez, 1983, pp. 252-253).

${ }^{30}$ Cf. "Bulla do Papa Leão X dirigida a el-Rei. 1514 - Junho 7" (Corpo Diplomatico Portuguez, 1983, pp. 254 ss).

${ }^{31}$ Cf. "Bulla do Papa Leão X. 1514 - Junho 12" (Corpo Diplomatico Portuguez, 1983, pp. 257-260).
} 
Em bula de 14 de Setembro, o pontífice concede indulgências aos participantes da expansão ${ }^{32}$. Depois, com data de 24 do mês seguinte, destaca-se a "Carta de notificação da graça concedida pelo Santo Padre, Leão X, como por seus embaixadores fora requerido, havendo respeito ao muito serviço que na guerra dos mouros faziam, com muito trabalho, fadiga, despesa, perigos e mortes, pudesse el-rei haver pelos mosteiros e igrejas, das colações dos prelados" 33 .

Numa quinta bula, de 3 de Novembro, confirma a doação e concessão de Nicolau $V$ (1397-1455, papa desde 1447), Calisto III (1378-1458, papa desde 1455) e Sisto IV de todas as terras e províncias conquistadas e por conquistar, não apenas na Índia mas também em terras desconhecidas ${ }^{34}$

Leão X ofereceu ainda a D. Manuel um volume iluminado, provavelmente um Livro de Horas, bem como uma suposta chaminé de mármore branco da autoria de Miguel Ângelo, que terá inicialmente sido montada no Palácio de Almeirim onde perdurou até ao Terramoto de 1755 (CARDOSO, 2001, p. 73).

Mas o culminar das benesses de Leão $X$ ao rei português acontece quando a 30 de Janeiro de $1515^{35}$ atribui a D. Manuel os prestigiados Gladius et Pileus (espada papal e barrete ducal), que constituem à época a mais alta condecoração que um príncipe cristão podia receber do papado, "como símbolos do poder real de campeão da fé na República cristã" (ANDRADE, 1974, p. 129). Nunca atribuída a um rei português, o grande valor desta distinção residia não na "matéria" mas antes no "mysterio", como assinalava o próprio pontífice. Dado Tristão da Cunha já ter regressado ao reino, coube a João de Faria ser o portador da distinta oferenda papal (Relações de Pero de Alcáçova Carneiro...,1937, p. 196-197): "neste tempo deu o papa ho estoque ao doutor João de faria pera el Rei de portugual. E elle se veo mandando sua alteza dom miguel a Roma por seu embaixador." (Memórias, fl. 211r).

Em síntese, profundamente politizada, a embaixada de obediência ao papa enviada por D. Manuel a Roma constitui o grande momento diplomático testemunhado pelas Memórias e o instante por excelência em que o Fidalgo evidencia a importância crescente da

\footnotetext{
${ }^{32}$ Cf. "Bulla do Papa Leão X. 1514 - Setembro 14." (Corpo Diplomatico Portuguez, 1983, p. 269-271).

${ }^{33}$ Arquivo Nacional da Torre do Tombo, Chancelaria de D. Manuel I, liv. 15, f. 150v.

${ }^{34}$ Transcrevendo inclusive as respectivas bulas dos dois últimos pontífices. Cf. "Bulla do Papa Leão X dirigida a el-Rei. 1514 - Novembro 3" (Corpo Diplomatico Portuguez, 1983, p. 275-298).

35 “Breve do Papa Leão X dirigido a el-Rei. 1515 - Janeiro 30." (Corpo Diplomatico Portuguez, 1983, p. 309-310).
} 
simbólica e da representação do poder nos alvores do novo século. Noutra vertente, revela em extensão e profundidade o papel estruturante desempenhado por Roma na construção do império ultramarino de Portugal. Afinal, é da capital da Cristandade que vem a validade e o reconhecimento último da legitimidade internacional do projecto expansionista português.

D. Manuel revela-se ao mundo cristão ao mesmo tempo que a diplomacia portuguesa oferece ao Sumo Pontífice o mundo descoberto e dominado pelo rei de Portugal, em prol da expansão da fé cristã. E é o próprio papa Leão X quem confirma este acto supremo de propaganda e simbólica do poder na missiva que envia ao rei português (Memórias, fl. 174v). A carta enviada por Leão X a D. Manuel - que o Fidalgo transcreve no seu texto ${ }^{36}$ - na sequência da tomada de Azamor, reflecte bem a firmeza do apoio concedido pelo pontífice ao rei português no seu empreendimento além-mar. Um apoio maximizado pelo facto de a gesta portuguesa servir de exemplo aos restantes reis cristãos acerca do caminho a seguir e dos erros a evitar.

A entrada em Roma mediante um cortejo público tão exótico quanto grandioso torna-se de imediato sinónimo de difusão e fixação internacional de uma imagem de poder não já limitada às fronteiras da Velha Europa. À cabeça de uma nação já essencialmente intercontinental, o rei D. Manuel tem de apresentar uma diplomacia tão sólida quanto eficaz e inovadora, de acordo, afinal, com os novos tempos que se vivem na Europa. Até porque os interesses internacionais de Portugal afirmam-se num novo contexto político europeu, pautado pelo facto de as monarquias em ascensão verem os seus destinos de forma interligada através das políticas dinásticas e da consolidação das redes familiares entre os soberanos.

De reter que ao longo de todo este convulso período, Portugal mantém uma cautelosa política de neutralidade em relação aos assuntos bélicos intra-europeus, em particular no que respeita às Guerras de Itália, um verdadeiro sorvedouro de homens e recursos que não permite às nações envolvidas virarem a sua atenção para o perigo Turco (SETTON, 1984). Damião de Góis é peremptório neste aspecto (GÓIS, Vol. III, 1926, p. 100).

\footnotetext{
${ }^{36} \mathrm{O}$ Fidalgo transcreve a versão portuguesa do breve Saepe egimus, de 18 de Janeiro de 1514, no qual Leão $\mathrm{X}$ felicita D. Manuel pela tomada de Azamor (Memórias, fls. 174v a fl. 176r). Cf. "Breve do Papa Leão X dirigido a el-Rei. 1514 - Janeiro 18." (Corpo Diplomatico Portuguez, 1983, pp. 214-216). Esta missiva papal surge como resposta à carta enviada por D. Manuel ao pontífice romano no final do mês de Setembro de 1513. Cf. "Carta de el-Rei ao Papa Leão X. 1513 - Setembro 30." (Corpo Diplomatico Portuguez, 1983, p. 207-209).
} 
No entanto, no que se refere ao combate à ameaça turca a Oriente e ao muçulmano no Norte de África, Portugal assume uma posição de vanguarda. O papado reconhece e celebra a política externa lusa (Memórias, fls. 173v a 176r).

O Fidalgo de Chaves faz, pois, evidenciar na sua narrativa como, ao nível da política externa, se davam em Portugal os primeiros passos rumo a uma nova realidade política - o império - e a forma como se agendava o contacto com a Santa Sé para legitimar tal ambição. A actividade diplomática portuguesa em Roma é, aliás, tanto mais importante e sensível quanto o facto de a Coroa desejar manter uma prudente política de neutralidade face aos conflitos europeus.

As Memórias apresentam-se, por tudo isto, como um retrato nítido da urgência da Coroa lusa em assumir de forma decidida o papel de líder de um vasto e diversificado domínio, um domínio intercontinental. Afinal, para atingir os seus objectivos expansionistas, Portugal tem necessidade da centralidade de Roma e do reconhecimento internacional que ela proporcionava (GOUVEIA, 1989; MACEDO, 1978; MARTÍNEZ, 2010). Todo e qualquer desenvolvimento das relações entre as Casas reinantes, ou seja, das monarquias em ascensão, passava invariavelmente pela Cidade Eterna.

5. O envio de uma segunda embaixada a Leão $X$

Ainda no quadro da embaixada de obediência a Leão $X$, o Fidalgo de Chaves dá também notícia do envio a Roma por $D$. Manuel de uma segunda delegação diplomática, onde merecia destaque o famoso rinoceronte indiano ${ }^{37}$ oferecido pelo rei de Cambaia, em 1514, a Afonso de Albuquerque (1453-1515), então governador do Estado Português da Índia ${ }^{38}$ :

el Rei de frança [...] chegou a marselha a tempo que vio a nao del Rei de portugual em que mandaua ao papa o Roinaçerom com outras Ricas Joias, o qual Ja a Rainha sua molher fora ver. diziasse que esta fora a causa por que se a nao perdeo [...]. da Riqueza que leuaua se fala muito em Roma. E muitos foram desta perda tristes polla parte dos presentes que esperauam. (Memórias, fl. 211v)

\footnotetext{
37 Conhecido por "Ganda".

${ }^{38} \mathrm{Em} \mathrm{1514}$, Afonso de Albuquerque enviou embaixadores ao Sultão Muzafar II de Cambaia, pedindo autorização para a construção de uma fortaleza em Diu. A missão não teve sucesso, contudo registou-se a tradicional troca diplomática de oferendas, a qual incluiu um rinoceronte indiano. Albuquerque decidiu enviar o rinoceronte ao Rei D. Manuel I (chegou a Lisboa no dia 20 de Maio de 1515), que por sua vez o enviou como presente ao Papa Leão X (Bedini, 1997, p. 112). Afonso de Albuquerque foi Governador e Vice-rei da Índia entre 1509 e 1515.
} 
Infelizmente, o papa nunca chegou a ver o exótico animal vivo, pois a embarcação que o transportava naufragou na costa italiana, em $1516^{39}$. Pelas palavras do autor podemos vislumbrar a expectativa que rodeava a chegada desta nau a Roma. Até o poderoso rei de França deslocou-se rapidamente a Marselha para ver o animal que o soberano português enviava ao papa. Isto para além de, como o autor indica, todo um manancial de riquezas que compunha as oferendas ao pontífice.

Certamente inspirada no sucesso político da antecessora embaixada, esta segunda delegação visava, num subsequente movimento diplomático, intensificar os esforços para a concretização satisfatória de um projecto político internacional, cujo ponto-chave residia agora em "pressionar" o papado a tomar uma decisão em favor de Portugal na sensível questão da posse das ilhas de Maluco e da demarcação das zonas de influência no ExtremoOriente e no oceano Pacífico.

Estamos, pois, perante uma tentativa diplomática do monarca português de desenvolver pressões políticas no Vaticano. É que, apesar de todas as vicissitudes provocadas pelo desenvolvimento das Guerras de Itália, o pontificado continua à época a representar a autoridade supra-nacional na Republica Christiana e, consequentemente, a assumir a figura de árbitro nas grandes contendas geopolíticas de então entre as principais nações cristãs, como por exemplo relativamente à partilha do mundo entre Portugal e Castela-Aragão.

A partir do momento em que o castelhano Vasco Nuñez de Balboa (1475-1519) avistou o Mar del Sur, mais tarde baptizado de oceano Pacífico, atravessando o istmo do Panamá (Setembro/Outubro de 1513), a corte portuguesa ficou consciente de que a sua posição de potência europeia dominante no outro lado do globo estava comprometida. Em simultâneo, chegado o final do ano da coroação do novo papa, a corte romana estava sensibilizada para esta delicada questão da contenda entre portugueses e espanhóis em tão longínquas paragens. O problema residia em que os castelhanos tinham agora uma rota potencial, alternativa à portuguesa, para atingirem as ilhas das especiarias, bem como a China. Não querendo perder a oportunidade de garantir o favoritismo do novo pontífice nesta disputa, D. Manuel aproveitou todo o recente apoio publicamente demonstrado pela cúria para enviar uma nova embaixada, agora centrada na oferenda de uma figura mítica medieval

\footnotetext{
39 Viu-o, posteriormente, mas empalhado, o que ainda assim lhe causou grande espanto, nas palavras do embaixador D. Miguel da Silva.
} 
- o rinoceronte -, que para mais era vista como o inimigo mortal do elefante já estante em Roma.

O monarca visava desta forma surpreender politicamente o país vizinho, fazendo pender para o lado de Portugal a balança de uma disputa diplomática que se revelava da máxima importância geoestratégica, pois estava em causa consumar um feito diplomático equivalente ao Tratado de Tordesilhas, desta feita para a extremidade oriental do continente asiático e para o oceano Pacífico, através da demarcação de um meridiano entre as zonas de influência portuguesa e espanhola. O propósito último seria, pois, assegurar o domínio incontestável das ilhas das especiarias situadas para além de Malaca, as Molucas, e possibilitar o acesso livre às costas de Cataio e de Cipango, estabelecendo, na sequência, estratégicos entrepostos comerciais - e se possível militares - nestas paragens mais distantes do mundo. Seria a concretização de uma parte importante das já referidas ambições imperiais manuelinas.

Apesar de Roma não ter assistido à entrada do Roinaçerom no seu espaço, esta oferenda não deixou de ter impacto na cultura europeia da época. Com efeito, tal evento proporcionou a circulação de um largo número de notícias, constituindo o ponto alto deste fenómeno de divulgação cultural o célebre desenho de Albert Dürer (1471-1528) ${ }^{40}$. Mostrando um animal nunca visto na Europa desde a Roma dos Césares, a imagem criada pelo gravador, pintor e ilustrador alemão, foi reproduzida e divulgada por todo o continente.

Após chegar a Lisboa, o animal foi examinado por curiosos e estudiosos, tendo sido enviadas para diversos destinos da Europa cartas pessoais com descrições da fantástica criatura. Emblemáticas são duas missivas enviadas poucas semanas após a chegada do animal à capital portuguesa. Uma da autoria de Valentim Fernandes (14[??] -c.1518), membro da comunidade germânica em Lisboa, enviada para um anónimo mercador de Nuremberga; e outra igualmente enviada para um desconhecido mercador de Nuremberga, que inclui uma descrição do rinoceronte e um esboço do mesmo, e que acabou por chegar às mãos de Dürer. Nesta última destaca-se uma passagem, que este artista irá reproduzir no topo da sua célebre xilogravura (BEDINI, 1997, pp. 119-121).

\footnotetext{
${ }^{40}$ Em 1512, Dürer ascendeu ao cargo de pintor de corte de Maximiliano I. Perfeitamente imbuído do espírito humanista do Renascimento, contactou com diversos pintores e homens de letras, nomeadamente Erasmo de Roterdão.
} 
Na essência, ambas as embaixadas constituem um espelho da corte e do monarca que as projectou e enviou. E, nessa medida, acabam por traduzir mais ou menos fielmente a política externa e as intenções deste no quadro da geoestratégia coeva da Europa. A forma como são programadas e postas em prática aliada à semântica geral e à simbólica final fazem delas, a um tempo, um poderoso instrumento do poder que pretendem representar.

Em ambos os casos, D. Manuel mostra a Roma o seu poderio, em especial o que the advinha do domínio do Oriente, para legitimar o seu programa expansionista. Teatralização do poder real? Sem dúvida! Mas com um alcance sem precedentes ao nível dos resultados, pois ambos os cortejos régios, sobretudo o de Tristão da Cunha da 1514, apresentam, além dos atributos do rei de Portugal, os símbolos do seu projecto messiânico e imperial.

Nesse sentido, as comitivas constituem notáveis peça de oratória e de propaganda política e ideológica, pois como salienta Américo da Costa Ramalho "a corte papal era uma espécie de fórum internacional onde os países cristãos se encontravam, aproveitando cada um deles a cerimónia de obediência para expor os serviços prestados à cristandade e o seu direito ao reconhecimento colectivo" (RAMALHO, 2000, p. 28). Também o investigador Luís de Matos assinala que "I'apparat fastueux que revêtaient parfois de telles cérémonies leur assuraient une large publicité, car ces ambassades d'obédience ne passaient nullement inaperçues à Rome et du côté portugais on tenait à leur éclat." (MATOS, 1991, p. 163)

Se no século XV as embaixadas à cúria romana, nomeadamente as de obediência, constituíam uma forma solene de vassalagem dos príncipes ao papa, a partir dos inícios do século XVI passou-se a acrescentar a esta função a de extraordinário e eloquente meio de divulgação e propaganda ideológica. A embaixada era o príncipe. Pelo que, quanto mais rica, faustosa e impressionante fosse mais este era invejado, temido e respeitado pelos pares, pela cúria e, superior objectivo de quem a enviava, pelo detentor da cátedra de S. Pedro.

6. A necessidade de um embaixador permanente em Roma

Como temos vindo a verificar, dada a centralidade de Roma nas disputas internacionais e na busca de validade e legitimação para projectos ultramarinos, por um lado, e as pretensões expansionistas específicas de Portugal, por outro, tornou-se urgente para D. Manuel garantir um embaixador permanente no coração da Cristandade. 
Noutra vertente, a capital da Cristandade constituía à época o centro de todo um sistema informativo entre o Extremo e Médio Oriente e a Europa; estado de coisas de particular interesse para Portugal dadas as suas ambições imperiais e o inevitável choque com os interesses turcos no Oriente (CRUZ, 1969, p. 463-467; CARDIM, 2004, p. 11-53).

É o que o Fidalgo demonstra quando evoca a figura de João de Faria, primeiro embaixador português permanente na cúria papal, ou a chegada a Roma de D. Miguel da Silva $(1480-1556)^{41}$ para substituir aquele no cargo (Memórias, fls. 153v e 154r; 211r).

Também ao descrever a presença de Tristão da Cunha em Itália, o autor dá a ver a emergência do contacto assíduo entre o rei e o embaixador seu representante numa missão específica: "os neguoçios de tristão da cunha eram de calidade que lhe conveo fazer detença em Roma tres meses por mandar Recados E avisos a el Rei, E aver Reposta de sua alteza" (Memórias, fl. 181v).

Ao mesmo tempo que se assumiam como o coração e o eixo político da Cristandade, Roma e em especial a cúria pontifícia afirmavam-se cada vez mais como centro privilegiado de informação universal (CRUZ, 1969, p. 463-467; BARATA, 1991). Todas as notícias de carácter político e geoestratégico importantes passavam pela Cidade Eterna, pelo que era vital e urgente às monarquias europeias aí manterem uma presença constante, por forma a estarem o mais bem informados possível acerca dos desenvolvimentos governativos e das grandes decisões políticas tomadas no Velho Continente que passavam, invariavelmente, pelo conhecimento do papado ${ }^{42}$.

Neste sentido, não estranha que a Coroa portuguesa acompanhe a tendência geral europeia de optar por representações diplomáticas permanentes em Roma com acções informativas paralelas, de que o estabelecimento de redes de agentes e contactos constitui provavelmente o melhor exemplo (CARDIM, 2004, p. 627-660; CARDIM, 2004, p. 11-53).

\footnotetext{
${ }^{41}$ Embaixador permanente em Roma entre 1514 e 1525, D. Miguel da Silva foi um dos diplomatas e intelectuais portugueses mais eminentes do Renascimento. Foi bispo de Viseu, em 1526, e cardeal da Igreja Católica Romana, em 1539 (DESWARTE-ROSA, 1989 e 1993).

${ }^{42}$ Como salienta Yves Renouard, "Roma era o centro postal internacional mais activo de Itália e, sem dúvida, da Europa: as novas políticas militares, comerciais, espirituais aí convergiam e daí partiam por todas as vias. A Cidade Eterna era o centro mais bem informado das novas de toda a Cristandade, e aquele donde elas eram difundidas em todas as direcções." (CRUZ e LÁZARO, 2004 , p. 602)
} 
O contexto internacional no despertar quinhentista obrigava Portugal a ter os olhos postos em Roma. Afinal, o que aí se decidia em termos políticos, militares e económicos, acabava por se repercutir naquilo que era o centro de interesses da política externa portuguesa. Nessa medida, era vital protagonizar uma permanente intervenção diplomática oficial (e não oficial) em Roma (BRASÃO, 1973).

Conclusão

Acompanhando de perto o furor politicus que atravessa a Europa no início do século XVI - claramente devedor da emergência das monarquias nacionais e da ascensão das principais Casas dinásticas europeias -, as Memórias revelam como à época o reino de Portugal necessita da centralidade romana para fazer valer as suas ambições imperiais. Neste quadro, a política externa e, em consequência, a actividade diplomática ganham um protagonismo singular e sem precedentes (CARDIM, 2004, p. 13).

O seu autor mostra como as embaixadas de obediência de D. Manuel a Roma se assemelham a um monumental triunfo do rei português e do povo que lidera. Uma extraordinária ostentação simbólica de poder, que, à época, assumia um carácter global na medida em que envolvia os mais longínquos lugares do mundo, recentemente reequacionado pelas navegações de portugueses e castelhanos. O rei português dá-se em espectáculo e à boa maneira da Roma renascentista, o espectáculo é muito bem acolhido. Um, enfim, genuíno paradigma da eficácia da propaganda política.

A sede da Cristandade distingue-se pela espiritualidade, pela cultura, pelo cosmopolitismo, mas também, de forma vital, pela política. Na essência, a Cidade Eterna assume nos alvores de Quinhentos a sua capitalidade no jogo da política internacional, tornando-se polo de confluência de toda uma imensa rede de mobilidades políticodiplomáticas que abarca a grande maioria da Europa. Em jogo está, por um lado, a hegemonia sobre a Europa, e, por outro, a formação de impérios ultramarinos, onde merece destaque o projecto português. Com efeito, esse periférico e pequeno reino que as viagens marítimas e a chegada à Índia, em 1498, trouxeram para uma posição de destaque, ganha protagonismo neste intenso palco internacional onde combatem entre si as mais fortes e ambiciosas nações da Cristandade ocidental. Disso dá conta, de forma evocativa, o testemunho do anónimo Fidalgo de Chaves. 


\section{REFERÊNCIAS BIBLIOGRAFICAS}

AMADO, Teresa. Os géneros e o trabalho textual. ALMEIDA RIBEIRO, Cristina; MADUREIRA, Margarida (coord.) O Género do Texto Medieval. Actas do 1. Colóquio Organizado pela Secção Portuguesa da Associação Hispânica de Literatura Medieval (1996). Lisboa: Cosmos, p. 9-28, 1997.

ANDRADE, António Alberto Banha de. História de um fidalgo quinhentista português, Tristão da Cunha. Lisboa: Instituto de História Infante Dom Henrique, 1974.

ARAÚJO, Renata de. Lisboa a Cidade e o Espectáculo na Época dos Descobrimentos. Lisboa: Livros Horizonte, 1990.

BARATA, Maria Temudo. Os Diplomatas Portugueses em Roma no Século XVI e as Informações Acerca do Turco e da Índia. Lisboa: Faculdade de Letras da Universidade de Lisboa, 1991.

BEDINI, Silvio. The Pope's Elephant: Aspects of Portugal. Manchester/Lisbon: Carcanet/Calouste Gulbenkian Foundation/Discoveries Commission, 1997.

BELY, Lucien. L'art de la paix en Europe. Naissance de la diplomatie moderne XVie-XVIle siècle. Paris : PUF, 2008.

BRASÃO, Eduardo. Relações diplomáticas de Portugal com a Santa Sé, 3 vols. Lisboa: Academia Internacional da Cultura Portuguesa, 1973.

CARDIM, Pedro. A Diplomacia Portuguesa no Tempo de D. João III: Entre o Império e a Reputação. CARNEIRO, Roberto; MATOS, Artur Teodoro de (dir.). D. João III e o Império. Actas do Congresso Internacional Comemorativo do Seu Nascimento, Lisboa, 2004. Lisboa: Centro de História de Além-Mar e CEPCEP, p. 627-660, 2004.

A prática diplomática na Europa do Antigo Regime. RODRIGUES, Luís Nuno; MARTINS, Fernando (ed.). História e Relações Internacionais. Temas e Debates. Lisboa: Edições Colibri/CIDEHUS/Universidade de Évora, p. 11-53, 2004.

CARDOSO, Arnaldo Pinto. A Presença Portuguesa em Roma. Lisboa: Quetzal, 2001.

CASTRO, Aníbal Pinto de. Uma Voz do Diálogo Luso-Italiano na Época de Quinhentos, a do 'Fidalgo de Chaves'. Mare Liberum, n. 2. Lisboa: CNCDP, p. 7-16, 1991.

Corpo Diplomatico Portuguez: Contendo os Actos e Relações Politicas e Diplomáticas de Portugal com as Diversas Potencias do Mundo Desde o Século XVI Até os Nossos Dias. vol. I. Luís Augusto REBELO DA SILVA (ed.). Lisboa: Academia das Ciências de Lisboa, 1983.

CRUZ, Maria Augusta Lima. Contribuição Para o Estudo dos Correios Entre Portugal e Roma no Século XVI. Paris: Fundação Calouste Gulbenkian (Centro Cultural Português), 1969.

CRUZ, Maria Augusta Lima, LÁZARO, António Manuel. A Linguagem Criptográfica na Correspondência Diplomática Portuguesa de D. Miguel da Silva e de Pero Correia: Origens e Significado. CARNEIRO, Roberto; MATOS, Artur Teodoro de (dir.). D. João III e o Império. Actas do Congresso Internacional Comemorativo do Seu Nascimento, Lisboa, 2004. Lisboa: Centro de História de Além-Mar e CEPCEP, p. 601-620, 2004.

DESWARTE-ROSA, Sylvie. Il Perfetto Cortegiano D. Miguel da Silva. Roma: Bulzoni, 1989. 
Un Nouvel Age d'Or: la Glorie des Portugais à Rome Sous Jules II et Léon X. Coimbra: Faculdade de Letras da Universidade de Coimbra, 1993.

EUGENIO ASENSIO. Memórias de Um Fidalgo de Chaves (1510-1517), descripción de la Roma de Julio II y Léon X. Memórias da Academia das Ciências, Classe Letras, tomo XIII. Lisboa: Academia das Ciências, p. 7-28, 1970.

FROMMEL, Christoph. Architettura alla corte papale nel Rinascimento. Milano: Electa, 2003.

GIOVIO, Paolo. Elogios o vidas breves de los cavaleros [Elogia virorum bellica virtute illustrium veris imaginibus supposita, quae apud Musaeum spectantur, Florence, Officina Laurentii Torrentini Ducalis Typographi, 1551, Trad. de Baeça]. Granada: Aleigo de Mena, 1568.

GÓIS, Damião de. Crónica do felicíssimo rei D. Manuel. Joaquim de Carvalho e David Lopes (ed.), vol. III. Coimbra: Imprensa da Universidade, 1926.

GOUVEIA, António Camões. De Lisboa a Roma para mostrar a Índia. Noesis, Lisboa, n. 22, p. 24-27, 1992.

. Portugal e a Europa: a sociedade e as relações diplomáticas de Tordesilhas aos Pirenéus. Revista ICALP, 15, Lisboa, p. 89-95, 1989.

GREGOROVIUS, Ferdinand. Storia di Roma nel medioevo, vol. VI, 1503-1534. Roma: Newton Compton Italiana, 1972.

HESPANHA, António Manuel. História das Instituições. Épocas Medieval e Moderna. Coimbra: Almedina, 1982.

JAUSS, Hans Robert. Toward an Aesthetic of Reception. Minneapolis: University of Minnesota Press, 1985.

LAPEYRE, Henri. Las monarquías europeas del siglo XVI: las relaciones internacionales. Barcelona: Labor, 1969.

MACEDO, Jorge Borges de. História Diplomática portuguesa, constantes e linhas de força. Lisboa: Instituto de Defesa Nacional, 1978;

MARTínEZ, Soares. História diplomática de Portugal. Coimbra: Almedina, 2010.

MATOS, Luís de. L'Expansion Portugaise dans la Littérature Latine de la Renaissance. Lisboa: Fundação Calouste Gulbenkian, 1991.

OSÓRIO, D. Jerónimo. Da vida e feitos de El-Rei Dom Manuel [De rebvs Emmanvelis regis Lvsitaniae invictissimi virtvte et avspicio gestis libri dvodecim, Lx., António Gonçalves, 1571], vol. II. Porto: Civilização, 1944.

RAMALHO, Américo da Costa. Humanismo em Portugal, Para a História do Humanismo em Portugal, vol. IV. Lisboa: INCM, p. 19-35, 2000.

REBELO, Luís de Sousa. A concepção do poder em Fernão Lopes. Lisboa: Livros Horizonte, 1991. 
Relações de Pero de Alcáçova Carneiro Conde da Idanha do Tempo Que Ele e Seu Pai, António Carneiro Serviram de Secretários: 1515 a 1568, Ernesto de Campos de Andrada (ed.). Lisboa: Imprensa Nacional, 1937.

RESENDE, Marquês de. Embaixada de el-rei D. Manuel ao papa Leão X. O Panorama, vol. XI (3ㅇ da 3a série). Lisboa, p. 219-222, 1854.

SALMANN, Jean-Michel. Géopolitique du XVIe siècle. 1498-1618. Paris: Seuil, 2003.

SETTON, Kenneth Meyer. The Papacy and the Levant, 1204-1571. Vol. III: The Sixteenth Century to the Reign of Julius III. Philadelphia: American Philosophical Society, 1984.

TENENTI, Alberto. La formación del mundo moderno, Siglos XIV-XVII. Barcelona: Editorial Crítica, 1985.

THOMAZ, Luís Filipe. Cruzada, Dicionário de História Religiosa de Portugal, vol. c-i. Lisboa: Círculo de Leitores, p. 31-38, 2000.

L'Idée Impériale Manuéline, La Découverte, le Portugal et L'Europe. Actes du Colloque, Jean Aubin (ed.). Paris : Centre Culturel Portugais, p. 35-103, 1990.

TOMBO, Arquivo Nacional da Torre do. Chancelaria de D. Manuel I, liv. 15, f. 150v.

TURNBULL, Stephen. The Ottoman Empire 1326-1699. New York: Routledge, 2003. 